\title{
AN ALTERATION IN GENE FREQUENCY IN RICINUS COMMUNIS L. DUE TO CLIMATIC CONDITIONS
}

\author{
BY SYDNEY C. HARLAND \\ Institute of Cotton Genetics, National Agricultural Society, Lima, Peru
}

INTRODUCTION

Received 22.xii.46

THE observations described in this note were made during the course of some genetical experiments with the Gastor Bean, Ricinus communis L.

In Ricinus, the presence and absence of a waxy bloom on the stem form a simple pair of allelomorphic characters, symbolised as :

$B$-presence of bloom, and $b$-absence of bloom (White, 1918). White's results were confirmed by Harland (I918). Peat (1928) worked on the mode of inheritance of double bloom, in which there was an extension of wax to the under side of the leaf. He noted a type called "triple bloom" in which there was a further extension of wax to the upper surface of the leaf. The genetics of "triple" was not studied. Peat found three pairs of genes governing the interrelationship of double bloom, single bloom and no bloom. In addition to the $B-b$ pair of White and Harland, there are also :

$C$-Bloom on under surface of leaf ; manifested only in presence of $B$. Intensifies effect of $B$ on stem, petioles and capsules.

$c$-Absence of bloom.

$D$ - Heavy bloom on stem, petioles and capsules (may be masked if $C$ is present) ; only visible in presence of $B$.

$d$-Light bloom on stem.

In the present experiments only the gene pair $B-b$ was present, giving in absence of $D$, light bloom on stem and petiole.

\section{DISTRIBUTION OF RICINUS COMMUNIS L.}

The centre of origin of Ricinus, which is a monotypic genus, is said to be Abyssinia, though it is now a cosmopolitan and occasionally aggressive weed of the Tropics and sub-Tropics. It is highly polymorphic, and many cultivated forms are known.

In Peru it occurs along the whole of the coastal belt from Tumbes lat. $4^{\circ} \mathrm{S}$. to Tacna $18^{\circ} \mathrm{S}$., a distance of about 1200 miles. It is also found in the narrow valleys which are the outlets for the swift though small torrential streams which rise in the Andes. At lat. $12^{\circ} \mathrm{S}$. the last plants of Ricinus are at about 7700 feet. 


\section{CLIMATIC FEATURES OF THE COASTAL BELT}

Near Lima, where the experiments to be described were carried out, the main features of the climate are as follows : "From November to April there are usually constant dryness, a clear sky and considerable, though by no means oppressive, heat. From June to September the sky is obscured for weeks together by fog, which is often accompanied by drizzling rain called garua." * The climate in the winter season is thus damp and disagreeable, with temperatures low enough to make some form of domestic heating almost a necessity.

For this climate the Humboldt current is responsible. The temperature records in degrees Centigrade for a year in Lima (lat. $12^{\circ} 04^{\prime} 30^{\prime \prime} \mathrm{S}$.) are as follows :-

\begin{tabular}{cccccccccccrr}
\multicolumn{2}{c}{ Jan. $\dagger$} & Feb. & Mar. Apr. & May & June & July & Aug. & Sept. & Oct. & Nov. Dec. \\
Mean max. & 28 & 29 & 29 & 26 & 24 & 22 & 19 & 19 & 20 & 21 & 23 & 25 \\
Mean min. & 19 & 19 & 18 & 17 & 17 & 15 & 13 & 12 & 13 & 13 & 15 & 16 \\
Mean & 24 & 24 & 23 & 22 & 21 & 19 & 19 & 14 & 15 & 16 & 18 & 20
\end{tabular}

No other tropical region has such an extraordinary climate, and it is thus found that some typical weeds of the temperate zone such as the dandelion (Taraxacum officinale) and plantain (Plantago major) are completely at home in the Lima lawns. From June to December most ordinary European vegetables are grown to perfection, and flowering plants from temperate regions also do well.

The thick fog which blankets a narrow zone along the coast rapidly thins out as the land rises towards the Andes, and in travelling up the Nimac valley, which leads from Lima inland, the fog bank disappears at from I 500 to 2000 feet, bright sunshine then prevailing throughout the year.

Sunshine records are available for two localities: (I) Lima city and (2) the Government Agricultural Station at La Molina, a few kilometres up the Rimac valley at a higher elevation.

\begin{tabular}{|c|c|c|c|c|c|c|c|c|c|c|c|c|c|c|}
\hline Site & $\begin{array}{c}\text { Elevation } \\
\text { metres }\end{array}$ & Jan. & Feb. & Mar. & April & $\begin{array}{c}\text { Sunsh } \\
\text { May }\end{array}$ & $\begin{array}{l}\text { hine } \mathrm{i} \\
\text { June }\end{array}$ & Ju & $\begin{array}{l}\text { ours: } \\
\text { Aug. }\end{array}$ & ${ }^{+}$Sept. & Oct. & Nov. & Dec. & Total \\
\hline & & & & & & & & & & & & & & \\
\hline olin & $25^{I}$ & 194 & 203 & 243 & 160 & 108 & 79 & 72 & 69 & $7^{\circ}$ & 123 & 156 & I 33 & 1610 \\
\hline
\end{tabular}

The increase in hours of sunshine caused by an increased elevation is quite marked, more especially from April to December.

Cloudiness indices are available for the same two localities, for the months of July to December inclusive. $\S$

\begin{tabular}{|c|c|c|c|c|c|c|}
\hline Site & July & Aug. & Sept. & Oct. & Nov. & Dec. \\
\hline $\begin{array}{l}\text { Lima } \\
\text { La Molina }\end{array}$ & $8 \cdot 3$ & $7 \cdot 9$ & $\begin{array}{l}8 \cdot 5 \\
8 \cdot 0\end{array}$ & $\begin{array}{l}8 \cdot 0 \\
6 \cdot 6\end{array}$ & $\begin{array}{l}6 \cdot 5 \\
5 \cdot 0\end{array}$ & $\begin{array}{l}6.9 \\
5.8\end{array}$ \\
\hline
\end{tabular}

Cloudiness at La Molina is markedly less than in Lima during the cold season, resulting from an elevation 140 metres higher. It is to

* Encyclopedia Britannica, i ith ed.

‡ January to June 1932. July to December 1935 . $\dagger$ January to June 1932. July to December 1935 . $\S$ Year 1935 . 
be regretted that similar sunshine and cloudiness records are not available for a series of elevations in the valley, but they would only serve to illustrate the main point-the specialised nature of the Lima climate, rapidly changing with altitude, which might thus be expected to act as an agent of natural selection, capable either of eliminating some genes altogether, or of causing marked changes in gene frequency in respect of others.

\section{THE EXPERIMENTAL RESULTS}

Genetic experiments with Ricinus are being carried out at the Experiment Station of the Institute of Cotton Genetics situated near sea-level between Lima and Callao. The special cross under study is :

$\mathrm{L} \quad \mathrm{S}$

Large seeded bloom type $(B B) \quad$ Small seeded no-bloom $(b b)$ from Sao Paulo, Brazil Peruvian coastal type

At the time the observations began in May 1943 there were available for study the following cultures :-

I. The $\mathrm{L}$ parent and a large progeny.

2. The $\mathrm{S}$ parent and a large progeny.

3. An $\mathrm{F}_{1}$ of 32 plants.

4. An $\mathrm{F}_{2}$ of 44 plants.

5. Back-cross of $F_{1} \times L$.

6. Back-cross of $F_{1} \times S$.

At the end of May 1943 it was noticed that the L parent, which as has been stated possessed the dominant $\mathbf{B}$ in a homozygous condition, ceased to fruit. Growth of meristems continued slowly, and inflorescences were still formed. Blackening of the apical meristems then occurred, and the inflorescences also blackened and shrivelled. The amount of viable pollen rapidly decreased until by the end of June none was being produced.

Observations of the $\mathrm{S}$ parent $(b)$ showed that fruiting continued throughout the cold season, though at a diminished rate, and there was no blackening of the inflorescences or apical meristems.

The $F_{1}$ plants were intermediate in behaviour and in development of bloom, though rather nearer to the B parent. Fruiting in the cold season was nearly though not absolutely stopped.

The $F_{2}$, which gave segregation into 3 bloom: I no-bloom, manifested behaviour like the parents. All the bloom plants had sterile and blackened inflorescences during the cold season; the no-bloom continued fruiting to the same degree as the $\mathrm{S}$ parent. Likewise in the back-cross of $F_{1}$ to $S$ the same classification of behaviour was observed, whereas the back-cross of $F_{1}$ to $L$ behaved uniformly like L. 


\section{Conclusion}

The inability of the bloom types to fruit in the cold and fog of the winter season of Lima must be due either to the fact that the presence of bloom is itself physiologically disadvantageous, or that some closely linked gene has this effect. It is probable that the first of these explanations is the correct one, since the correlation of cold season sterility and bloom is complete in all types of populations.

\section{EXAMINATION OF WILD POPULATION}

\section{The Lima area}

Ricinus is abundant in the city of Lima as an escape in unoccupied gardens, waste lands and roadsides. A survey was made of the Lima area and the following result was obtained :-

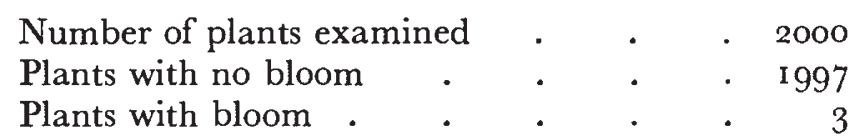

We have no knowledge of the genetic composition of the types which were introduced into this particular area of Peru, but from the fact that both bloom and no-bloom types have been noted in the West Indies, Brazil, Venezuela and Colombia in about equal numbers as well as in other parts of Peru, it seems likely that the original population contained a much larger proportion of $B$ genotypes. It is quite clear that the selection against the $B$ gene is very powerful, and this is due to the cessation of fruiting for several months of the year. In the short hot season the number of seeds produced by the bloom types is very small.

\section{From Limo inland to 7600 feet altitude}

There is a motor highway from Lima which, rapidly ascending, enables one to cross the first Cordillera of the Andes at over 16,000 feet. An examination was made of Ricinus populations along this highway.

\begin{tabular}{|c|c|c|c|c|}
\hline Kilometre & Altitude in feet & No bloom & Bloom & \\
\hline $\begin{array}{l}5^{-6} \\
26-28 \\
4^{0-41} \\
84\end{array}$ & $\begin{array}{r}585 \\
1950 \\
2762 \\
7764\end{array}$ & $\begin{array}{r}14 \\
72 \\
47 \\
0\end{array}$ & $\begin{array}{l}4 \\
31 \\
47 \\
23\end{array}$ & $\begin{array}{l}22 \cdot 2 \text { per cent. } \\
30 \cdot 1 \quad, \\
50 \cdot 0 \quad, \\
100 \quad,\end{array}$ \\
\hline
\end{tabular}

Here we see that passing inland up the mountain valley there is a rapid increase in the proportion of bloom types. It may be noted that at $\mathrm{km} \cdot 5^{-6}$ the amount of sun in winter is greater than in Lima, though unfortunately records are not available. By the time km. 25 is reached, approximately 2000 feet above sea-level, the cloud bank 
has practically disappeared, and there is much sunshine and warmth throughout the winter. In July to September there is a heavy mist at night which does not clear till between ten and eleven in the morning. Observation of the Ricinus population at km. 26-28 showed that while some blackening of growing points and flowering spikes occurred in the $B$ types in the middle of winter, fruiting in these types was continuous throughout the year though much slower in the cold season. Fruiting of the $b$ types was also diminished though to a less degree. It is to be noted that the last plants of Ricinus seen at an elevation of about 7750 feet were of the bloom type, showing that absence of sun, presence of fog or both, are responsible for winter sterility in Lima, and not merely a lowering of temperature.

\section{DISCUSSION}

The present case provides a good example of natural selection, and of how a specialised climate can act differentially on the two members of an allelomorphic pair $B-b$. The writer had noted the fact that natural populations of Ricinus practically always had both genotypes, but it was not formerly obvious that either member had any advantage over the other. Now it is clear that had seeds exclusively of the genotype $B B$ been introduced into the Lima area, Ricinus would be an uncommon plant.

\section{SUMMARY}

I. Presence and absence of a waxy bloom on the stems of Ricinus communis $\mathrm{L}$. is due to the pair of alleles $B-b$.

2. In the Lima area the $B$ plants do not reproduce in the winter season, irrespective of whether such plants occur in natural populations, in pure lines or in segregating families under experimental conditions. Reproduction of $b$ types continues throughout the winter season though at a diminished rate.

3. The proportion of $B$ plants in wild populations of the Lima area has been reduced to about $0 \cdot 15$ per cent. by this environmental sieve.

4. The proportion of $B$ plants augments with increasing elevation, with concomitant increase in amount of sunlight and diminution of fog.

\section{REFERENCES}

Harland, S. C. . . . . . - 1918. Agric. Newe, Barbados, 17, 100.

Peat, J. E. . . . . . . . . 1928. F. Genetics, 19, 373-389.

Whrte, O. E. . . . . . 1918. Brooklyn Botanic Gardens Memoirs, I, 513-520. 